\title{
Teachers' Conceptions and Choices of Assessment Tasks in a Nigerian Postgraduate Teacher Training
}

\author{
Monsurat O. Raji ${ }^{1}$, Dorcas S. Daramola ${ }^{2}$, Jumoke I. Oladele ${ }^{2}$ \\ ${ }^{1}$ Faculty of Education, University of Ottawa, Ottawa, Canada \\ ${ }^{2}$ Department of Social Sciences Education, Faculty of Education, \\ University of Ilorin, Ilorin, Kwara State, Nigeria \\ mraji055@uottawa.ca ${ }^{1}$
}

Received: 19 October 2020; Accepted: 22 November 2020; Published: 26 November 2020

To cite this article (APA): Raji, M. O., Daramola, D. S., \& Oladele, J. I. (2020). Teachers' conceptions and choices of assessment tasks in a Nigerian postgraduate teacher training. Asian Journal of Assessment in Teaching and Learning, 10(2), 82-93. https://doi.org/10.37134/ajatel.vol10.2.9.2020

To link to this article: https://doi.org/10.37134/ajatel.vol10.2.9.2020

\begin{abstract}
Student assessment is a process that entails the collection of evidence of learning in diverse and systematic ways to make judgments on students' learning. What then is the perception of this vital tool in the hands of the users (teachers)? This study investigates teachers' conceptions of assessment and their choices of assessment tasks in postgraduate teacher training. Action research with one group pretest-posttest design was adopted for the study. The survey used to collect data for this study has three sections (A, B, \& C). Section A elicits participants' personal information; Section B contains 20 different assessment tasks. Section C includes 26 items that examined participants' conceptions of assessment from four different sub-scales (school accountability, student accountability, improvement of teaching and learning, and irrelevance factors). The researchers further validated the survey, and the Alpha reliability coefficient of the whole scale was 0.85 . Data collected from twenty-eight randomly selected teachers out of forty-five were analyzed using descriptive measures and paired sample t-test. Findings revealed that teachers enact both summative and formative assessment tasks but with preferences for summative tasks. A significant difference in teachers' conception of assessment was recorded, but there was no significant difference in teachers' assessment conception based on gender. Recommendations are presented to improve the research knowledgebase on assessment in the Nigerian education context.
\end{abstract}

Keywords: Teachers, Assessment, Conceptions, Practices, Nigeria

\section{INTRODUCTION}

Assessment broadly refers to the processes involved in collecting, interpreting, and using information gathered by teachers and students from various sources to improve teaching and learning (Kane \& Wools, 2020). Since Black and Wiliam's (1998) submission on the centrality of assessment to student learning, assessment has witnessed more considerable attention from educators and researchers. Assessment in education serves multiple purposes, including certification, promotion, accreditation, accountability, measurement of achievement, and advancing (or supporting) learning (Black \& Wiliam, 2018). Currently, education institutions implement summative and formative assessments in evaluating student learning (Chu \& Fung, 2018; Vlachou, 2018).

Formative assessment is a form of assessment embedded within instruction, allows for the provision of feedback to students, and can improve student learning and teachers' instructional planning (Black \& Wiliam, 2018). Summative assessment, mostly enacted at the end of instruction, provides limited opportunity for teacher feedback, is often one-shot, and is mainly utilized for promotional, certification, and accountability purposes (Brookhart, 2011; McMillan, 2015). A review of assessment practices in schools indicates that students are primarily assessed through written and oral examinations and quizzes, with limited use of portfolios, projects, and peer and self-assessments (Chu \& Fung, 2018; Vlachou, 2018). 
In Canada, five secondary school mathematics teachers' classroom assessment practices in Ontario were explored through qualitative case studies to determine their use of authentic assessments in classrooms (Suurtamm, 2004). Suurtamm found that participant mathematics teachers implemented performance tasks, group projects, journals, and portfolios. This study concluded that, more often, participant teachers were "torn between delivering a curriculum that listed content topics and assumed a traditional teaching style and offering a problems-rich curriculum with a variety of teaching styles" (Suurtamm, 2004, p. 510). Therefore, for teachers to effectively implement authentic assessments, a curriculum that promotes such assessment activities should be designed and effected (Suurtamm, 2004). This study refers to an Ontario curriculum that has since been redesigned and now promotes contemporary forms of assessment.

As part of a large-scale project, Suurtamm, Koch, and Arden (2010) investigated grades seven to ten Ontario teachers' perceived comfort to implement various assessment techniques in their classrooms. The questionnaire data results revealed that $91 \%$ of the study participants were comfortable employing multiple assessment tools to enhance student learning. Teacher participants mentioned using paper-and-pencil tests, performance tasks, observations, notes/checklists, interviews/conferencing with students, student presentations, portfolios, projects, and self-assessment. An analysis of the specific tools these teachers frequently used in their practice to assess students' knowledge revealed that teachers relied mostly on quizzes and tests. Studies on teachers' assessment practices are context-specific (Brown, Gebril, \& Michaelides, 2019), and, in the case of Nigeria, has been argued as requiring continuous intervention (Omebe, 2014).

Classroom assessment, as presented in the Nigerian Policy on Education, is expected to contribute towards the advancement of student learning and skills (Federal Government of Nigeria FGN, 2013). Yet, Afemikhe and Omo-Egbekuse (2011) observed that Nigeria's situation is such that continuous testing is in vogue. Afemikhe and Omo-Egbekuse contend that Nigerian teachers mainly administer and grade tests and quizzes, whereas test results do not contribute towards the diagnostic and formative purposes of assessment (Brookhart, 2011).

Nwachukwu and Ogudo (2014) investigated secondary school teachers' use of cognitive, affective, and psychomotor domains of learning in their assessment practices. The authors report on responses obtained from 1080 teachers randomly selected from 20 rural and urban secondary schools in a southern state in Nigeria. This study suggests that most teachers do not assess students in the three domains of behavioural objectives, as stated in the NPE assessment guidelines. Specifically, teacher participants concentrated on assessing students' mental capacities only, leaving out the affective and psychomotor learning domains. In terms of teachers' frequency of use of assessment tools, teachers employed more written essays and multiple-choice tests than projects, observations, and student journals (Nwachukwu \& Ogudo, 2014). Results from Afemikhe and Omo-Egbekuse and Nwachukwu and Ogudo's studies indicate a dominant assessment culture among Nigerian teachers. The authors' studies point to the need for recurrent research on Nigerian teachers' classroom assessment practices (Ndubueze, Iyoke, Okoh, \& Akubuilo, 2015) to report on any likelihood change in practices.

Conclusions from studies (e. g. Ndubueze et al., 2015; Omebe, 2014) on Nigerian teachers' classroom assessment practices suggest the need to train teachers on implementing innovative assessments in schools. Likewise, Deneen and Brown (2016) argue that all efforts towards designing appropriate assessment training for teachers should commence by understanding the factors militating against teachers' effective implementation of quality classroom assessment. At the same time, records of teachers' views or conceptions of assessment will serve as a needs analysis for teacher training programs. When teachers' personal views of assessment and their engagement with innovative assessment are sought and reported, the complexity surrounding teachers' classroom assessment practices becomes clearer (DeLuca, Chapman-Chin, \& Klinger, 2019).

\section{TEACHERS' CONCEPTIONS AND PRACTICES OF ASSESSMENT}

The process of implementing classroom assessment involves the complex interaction of a variety of factors, including how teachers and students conceptualize assessment (Brown et al., 2019; Opre, 2015). Specifically, teachers' support or resistance towards the successful implementation of new and 
innovative classroom assessment may depend mainly on their conceptualization of assessment (Barnes, Fives, \& Dacey, 2015), student-teacher interaction, educational context, and cultural standards associated with gender roles (Brown et al., 2019; Offerdahl \& Tomanek, 2011). Segers and Tillema (2011) contend that "studying conceptions of assessment is of utmost relevance at a time when innovation of assessment practices is on the educational agenda" (p. 53), as seen in the Nigerian Policy on Education document (the Federal Republic of Nigeria-FGN, 2013). Studies need to focus on understanding teachers' and students' conceptions of assessment because their views about assessment can significantly impact teachers' classroom practices and students' academic performance (Brown, 2011).

The literature documents relationships between teachers' conceptions and practices of assessment (e. g., Gebril \& Brown, 2014; Opre, 2015; Remesal, 2011; Sadler \& Reiman, 2018); including some factors that influence teachers' conceptions and practices of assessment (Brown et al., 2019). Establishing a relationship between teachers' conceptions and practices of assessment is a complex process given societal, cultural, and political influences on teachers' classroom decisions (Opre, 2015). For example, Davis and Neitzel (2011) exemplified the complexity argued by Opre in a study with 15 fourth to seventh-grade teachers in the United States, exploring participants' experiences of enacting self-regulated learning and assessment. Davis and Neitzel (2011) reported that teachers did not engage students in self-regulated learning and assessment. Participant teachers stated that the imposition of assessment strategies by policymakers accounted for the conceptions and assessment strategies they implemented in classrooms.

Gebril and Brown (2014) document a similar report to those found in Davis and Neitzel's study among Egyptian teachers. Egyptian teachers reported how societal expectations, political reforms, and cultural dispositions influenced their classroom assessment practices and conceptions. Consequent to the above, Brown et al. (2019), Gebril (2017), and Remesal (2011) contend that teachers' conceptions and practices of assessment research are highly contextual, and a complex terrain deeply rooted in cultural and societal traditions. To validate Brown and colleagues' and Gebril's claims, Ayodele (2012) also submitted that Nigerian teachers lack the proper understanding of assessment due to their experiences from societal and cultural expectations of assessment.

Because of jurisdictional specificity in educational policies and curriculum across the world, it is crucial to investigate the relations between teachers' conceptions and assessment practices within the educational context in which they work. Analysis of the existing literature indicates that very few studies examined teachers' conceptions of assessment in Africa (e. g., Gebril \& Brown, 2014; Gebril \& Eid, 2017), while limited research explicitly explored Nigerian teachers' conceptions and practices of assessment. Among the few studies directed at understanding teachers' conceptions of assessment is a recent study that examined the conceptions of assessment held by 300 lower and middle school teachers in Kwara State, Nigeria (Ogunjimi \& Lawal, 2020).

While $60.5 \%$ of the teachers reportedly held positive conceptions, $39.5 \%$ reported negative notions of assessment. Finding from Ogunjimi and Lawal's (2020) study suggests that more teachers conceptualize assessment as an activity for improving students' learning outcomes than those who believe that assessment is for accountability purposes and irrelevant to education. The study also showed a non-significant difference in lower and middle school teachers' conception of classroom assessment based on gender and qualification (Ogunjimi \& Lawal, 2020). As impressive as Ogunjimi and Lawal's study appear, the authors did not examine teachers' conceptions alongside the assessment practices they implement in classrooms. Whereas, for most teachers, conceptions of assessment reflect better through the assessment practices they adopt in classrooms (Brown et al., 2019).

\section{TEACHERS' CONCEPTUAL CHANGE}

Findings from the literature imply that in addition to efforts geared at changing teachers' assessment practices to promote student learning, there is the need to change how teachers conceive of assessment (Offerdahl \& Tomanek, 2011). Consequently, examining the intricate connection between teachers' conceptions and assessment practices is essential for understanding and supporting teachers' implementation of contemporary assessment practices, especially in high-stakes examination cultures such as Nigeria. Most teacher conceptual change studies draw from the concept of teacher learning 
progressions to describe the developmental conceptual change process and consequent changes in teachers' classroom practices (DeLuca et al., 2019). Similarly, teacher learning involves the gradual advancement along a professional learning continuum supported by professional learning programs and resources (Jurow, Tracy, Hotchkiss, \& Kirshner, 2012; Tigelaar \& Beijaard, 2013).

During the gradual change in their conceptions, teachers progress from less sophisticated conceptions to more sophisticated ones (Offerdahl \& Tomanek, 2011), which implies that teachers advance from a 'letter' to the 'spirit' of assessment (DeLuca et al., 2019). Teachers with less sophisticated conceptions view assessment as teacher-centered, while those with more sophisticated conceptions think more of assessment as student-centered (Offerdahl \& Tomanek, 2011). Among a sample of instructors in a southwestern United States university, Offerdahl and Tomanek (2011) reported changes in instructors' conceptions of assessment from summative to a more formative purpose after two semesters of experimentation with formative assessment strategies.

Similarly, DeLuca et al. (2019) examined the gradual change in 88 elementary and secondary school teachers' conceptions and assessment practices while participating in a professional learning program focused on improving teachers' assessment for learning practices. Through five developmental stages: "(a) learning the letter, (b) practicing the letter, (c) responding to the letter, (d) adopting the spirit, and (e) leading the spirit" (p. 274), the authors observed how teachers progressed from the letter to the spirit of assessment for learning. Teachers at the 'learning the letter' of assessment stage were developing their confidence and knowledge of assessment for learning strategies, whereas those at the 'leading the spirit' stage shared their knowledge and experience of assessment formally and informally with colleagues to assist others in the learning process (DeLuca et al., 2019).

Consequent to reported changes in teachers' conceptions and practices of assessment after participating in professional development programs, our research sought to examine teachers' learning and conceptual advancement after participating in a teacher training course on assessment. Further, it is essential to note the dearth of research on Nigerian teachers' conception and classroom assessment practices in the literature. The absence of studies in this research area signifies that efforts towards improving classroom assessment in Nigerian schools have not included teachers' understanding of assessment and the connection to their classroom assessment practices. Notably, in Nigeria, there is a significant gap to be filled in educational research on assessment in the country since the Federal Ministry of Education continues to encourage teachers to practice assessment for the improvement of student learning in K-12 classrooms.

Effective classroom assessment is pivotal to improved knowledge and skills for students to contribute towards national development as well as prepare them for post-secondary education (Afemikhe \& Omo-Egbekuse, 2011). However, research points out that the goals set for educational assessment are possibly not achieved, as there has been a tremendous public outcry about the quality of students graduating from Nigerian schools (Ndubueze et al., 2015). Furthermore, some studies indicate that Nigerian teachers' classroom assessment practices are responsible for students' examination malpractices, failures, and limited skill acquisition (Ekuri, Egbai, \& Ita, 2011; Nwachukwu \& Ogudo, 2014). For example, Ekuri and colleagues (2011) argue that Nigerian teachers' assessment practices neglect the assessment of formative assessment skills, which are generally associated with students' personalities and characteristics. Thus, the purpose of this research is to examine in-service teachers' (who double as postgraduate students) conceptions and practices of assessment before and after participating in a teacher learning program on educational measurement and evaluation at a North-western Nigerian university.

\section{THEORETICAL FRAMEWORK}

This research's theoretical framework draws upon Brown's (2002) teachers' conceptions of assessment model. Brown (2002) identified four factors that explain how teachers conceptualize assessment: improvement of teaching and learning, accountability of teachers and schools, accountability of students, and irrelevance conceptions. Teachers who conceptualize assessment as an improvement of teaching and learning in most cases, have a constructivist view of learning and assume they must facilitate learning for students. Such teachers also view assessment as a process for 
obtaining information to help students achieve their learning goals (Brown, 2002; 2006). Teachers, who believe that assessment makes schools and teachers accountable, perceive assessment as a means to reward or penalize teachers' practices and also as an activity that requires them to openly defend their classroom teaching and assessment practices to stakeholders (Brown, 2006). Moreover, teachers holding the student accountability conception of assessment conceptualize assessment as the responsibility of students: "students are individually accountable for their learning through their performance on assessments" (Brown, 2002, p. 40). The irrelevance conception of assessment is grounded on teachers' conceptualization of assessment as a formal, rigid, imposed, and a testing process that has no valid identity in the teaching and learning of students (Brown, 2006).

\section{RESEARCH QUESTIONS}

Based on teachers' participation in an educational measurement and evaluation course, the following research questions and hypotheses guides this study:

RQ1. Is there any difference between teachers' choices of assessment tasks after attending an Educational Measurement and Evaluation course?

RQ2. Is there any difference between the pre-test and post-test scores of teachers' conceptions of assessment after attending an Educational Measurement and Evaluation course?

RQ3. Is there any difference between the pre-test and post-test scores of teachers' conceptions of assessment after attending an Educational Measurement and Evaluation course based on gender?

\section{RESEARCH HYPOTHESES}

$\mathbf{H}_{\mathbf{0 1}}$ : There is no significant difference between the pre-test and post-test scores of teachers' conceptions of assessment after attending an Educational Measurement and Evaluation course.

$\mathbf{H}_{\mathbf{0 2}}$ : There is no significant difference between the pre-test and post-test scores of teachers' conceptions of assessment after attending an Educational Measurement and Evaluation course based on gender.

\section{METHODOLOGY}

\section{Research Design}

This study employed an action research methodology with one group pretest-posttest design. Primarily, action research advances the professional learning of users. According to Owolabi (2016), action research is a form of applied research with the primary purpose of increasing or improving the quantity, impact, and justice of education for professional practice. It aims to solve a problem or achieve a goal in practice and uses a convenient sample that is immediately available. Findings from action research are often evaluated in terms of its local applicability rather than its universal validity. The description above authenticates Norton's (2009) submission that action research aims not to provide generalizations from research conclusions because context is essential in the research process. The present study's research questions sought to evaluate and improve teaching and learning among teachers (postgraduate students) in the Faculty of Education in a Nigerian Federal University. 


\section{Participant Recruitment}

The population for this study is one hundred and twenty-seven postgraduate (Masters students) in the Faculty of Education at a Federal University in Nigeria. These postgraduate students are in-service teachers from various disciplines/fields within the education sector. The educational background of teachers who participated in this study ranged from Bachelor's degree to Postgraduate Diploma degrees in the Faculty of Education. The target population consists of forty-five postgraduate students with regular attendance at an educational assessment course titled Educational Measurement and Evaluation in the Harmattan semester. Simple random sampling procedure was employed to select all the students who regularly attended the lecture for the study at both pre-test and post-test data collection stages. Twenty-eight participants completed the pre-test and post-test questionnaires, which formed the data analyzed for this study.

\section{Educational Assessment Course}

One of the required courses for prospective teachers in any Nigerian University is Educational Measurement and Evaluation. The course content includes concepts of measurement, assessment, evaluation, measurement scales, errors of measurement, validity, and reliability. It also incorporates educational measurement instruments and assessment tasks (achievement test, performance test, essays, objective, aptitude, and intelligence tests, self-assessment, peer assessment, embedded assessment, questionnaire, focus group discussion, portfolio, checklist, group work, project and so on) and principles of assessment development. Other objectives of the course include principles of test standardization and problems associated with the assessment of learners in Nigeria. The importance of this course to teachers' classroom practices necessitates its inclusion in the postgraduate curriculum in Nigerian post-secondary education. The course was taught for a total of twenty-four hours over 12 weeks during the harmattan semester of the 2019/2020 academic school calendar.

Assessment for Learning (AfL) strategies were implemented in the process of teaching the course. During the teaching, teachers (postgraduates) completed two different projects. In the first project, teachers chose a content unit in their area of specialization and developed 20 multiple-choice items following the principle of test construction. The second project was group work on assessment tasks. Each group was given an assessment task (focus group discussion, socio-metric, observation, etc.) to explore and write a report. Students presented their projects in the class; the course lecturer made necessary corrections after the presentations. These projects and presentations formed $40 \%$ of the students' final grades.

\section{The Instrument for Data Collection}

The instrument used for data collection in this study was adapted from the Teachers' Conceptions of Assessment Inventory designed by Brown (2006) with a reliability coefficient of 0.78 . The original scale includes 27 items with a 6-point Likert-scale response format. However, the instrument was restructured in the present study due to the educational level of the study's participants (postgraduates). Hence, a 26 item 4-point Likert-scale response format was administered to participants in this study regarding their conceptions of assessment. The survey used in this study consists of three sections (A, B, \& C). Section A elicits participants' personal information, and Section B contains 20 different assessment tasks and solicits participants' willingness to use each of them in their instruction. Section C includes 26 items that examined participants' conceptions of assessment from four different sub-scales (school accountability, student accountability, improvement of teaching and learning, and irrelevance factors).

There are five items for school accountability, eight items for student accountability, seven items for improvement of teaching and learning, and six items for irrelevant sub-scales. The adapted instrument was validated by two experts in the Educational Research, Measurement and Evaluation Department at a Nigerian University. Upon validation, the instrument was improved; the reliability co-efficient of the sub-scales (School Accountability, Students' Accountability, Improvement and Irrelevant) are $0.69,0.79,0.68,0.76$. Cronbach Alpha reliability coefficient of the whole scale was 0.85 . 


\section{Data Collection}

The scale was administered first as a pre-test at the beginning of the course and as a post-test at the end of the course. Although forty-five postgraduate students with regular attendance at an educational assessment course were the study's target population, data obtained from twenty-eight participants who responded to the scale (pre-test and post-test) was used for analysis. The number of participants who did not participate in this study reveals experimental mortality experienced, being a limitation of the study. However, since the study employed an action research methodology with one group pretestposttest design, Norton (2009) submitted that action research aims not to provide generalizations from research conclusions. Owolabi (2016) validates Norton's claim by explaining that action research is a form of applied research with the primary purpose of improving professional practice using a convenient and immediately available sample. Hence, valid/complete data from twenty-eight participants can be considered appropriate for the study.

\section{Data Analysis}

SPSS package program was employed to analyze the collected data. An appropriate statistical technique was determined by investigating the data normal distribution status through skewness and kurtosis of the sub-scales (Students Accountability, Students Accountability, Improvement and irrelevant). Skewness and kurtosis values of -.652 and -.353 for student accountability, -.119 and .693 for school accountability, -.419 and -.165 for improvement and .828 and -.103 for irrelevance sub-scales, they are all between the limits of -1 and +1 , which indicated that the scores obtained from the sub-scales exhibited a normal distribution. Thus, descriptive measures were employed to answer the research question on participants' change in choices of assessment tasks. At the same time, the Paired-Samples t-test was used to test the research hypotheses at 0.05 alpha level.

\section{RESULTS/FINDINGS}

Research Question One: Is there any difference between teachers' choices of assessment tasks after attending an Educational Measurement and Evaluation course?

Data on teachers' choices of assessment tasks for teachers who indicated a 'Yes' was subjected to analysis using percentages and percentage ranking. Ranked \% choice difference of $50 \%$ and above, is considered a meaningful (significant) difference, as shown in Table 1.

Table 1. Differences in respondents' choice of assessment tasks before and after the course

\begin{tabular}{|c|c|c|c|c|}
\hline Tasks & $\begin{array}{c}\text { Pre-test } \\
\text { (Before) } \\
\text { Yes-Freq. } \\
(\boldsymbol{\%})\end{array}$ & $\begin{array}{c}\text { Post-test } \\
\text { (After) } \\
\text { Yes-Freq. } \\
(\boldsymbol{\%})\end{array}$ & $\begin{array}{c}\text { \% Choice } \\
\text { Difference } \\
\text { pre-test and } \\
\text { post-test) }\end{array}$ & $\begin{array}{c}\text { \% Choice } \\
\text { Difference } \\
\text { Ranks }\end{array}$ \\
\hline Essay & $26(7.32)$ & $26(6.0)$ & 0 & $18^{\text {th }}$ \\
\hline Multiple Choice & $20(5.63)$ & $25(5.75)$ & 25 & $8^{\text {th }}$ \\
\hline Supply response/fill-in-the-gap & $9(2.53)$ & $17(3.91)$ & 88.8 & $3^{\text {rd }}$ \\
\hline Matching response & $11(3.10)$ & $17(3.91)$ & 54.54 & $4^{\text {th }}$ \\
\hline Alternative/True or false & $18(5.07)$ & $22(5.05)$ & 22.22 & $10^{\text {th }}$ \\
\hline Oral Examination & $20(5.63)$ & $18(4.14)$ & -10 & $20^{\text {th }}$ \\
\hline Drama & $6(1.70)$ & $12(2.75)$ & 100 & $1^{\text {st }}$ \\
\hline Presentation & $23(6.48)$ & $23(5.28)$ & 0 & $18^{\text {th }}$ \\
\hline Project & $21(5.92)$ & $23(5.28)$ & 9.52 & $16^{\text {th }}$ \\
\hline Group work & $26(7.32)$ & $27(6.20)$ & 3.84 & $17^{\text {th }}$ \\
\hline Portfolio & $11(3.10)$ & $13(2.98)$ & 18.18 & $12^{\text {th }}$ \\
\hline Performance task & $19(5.35)$ & $25(5.75)$ & 31.57 & $7^{\text {th }}$ \\
\hline Embedded assessment & $7(1.97)$ & $14(3.21)$ & 100 & $1^{\text {st }}$ \\
\hline Critical thinking test & $19(5.35)$ & $23(5.28)$ & 21.05 & $11^{\text {th }}$ \\
\hline
\end{tabular}




\begin{tabular}{|c|c|c|c|c|}
\hline Aptitude test & $19(5.35)$ & $26(6.0)$ & 36.84 & $6^{\text {th }}$ \\
\hline Observation & $22(6.20)$ & $26(6.0)$ & 18.18 & $12^{\text {th }}$ \\
\hline Socio-metric scale & $18(5.07)$ & $26(6.0)$ & 50 & $5^{\text {th }}$ \\
\hline Peer-assessment & $20(5.63)$ & $25(5.75)$ & 25 & $8^{\text {th }}$ \\
\hline Self-assessment & $23(6.48)$ & $27(6.20)$ & 17.39 & $14^{\text {th }}$ \\
\hline Checklist & $17(4.79)$ & $19(4.36)$ & 11.76 & $15^{\text {th }}$ \\
\hline TOTAL & $\mathbf{( 1 0 0 \% )}$ & $\mathbf{( 1 0 0 \% )}$ & & \\
\hline
\end{tabular}

Table 1 shows that after attending the course, teachers' (postgraduate students) assessment choices of drama, embedded assessment, supply response/fill-in-the-gap, matching response and socio-metric scale increased by $50 \%$ and above. Teachers' assessment preferences for multiplechoice, alternative/true or false, project, group work, portfolio, performance task, critical thinking test, aptitude test, observation, peer-assessment, self-assessment and checklist increased by less than $50 \%$. However, the teachers' choice of essay and presentation did not change while their oral examination choice decreased by $10 \%$. Hence, there are differences between teachers' assessment task choices after attending the Educational Measurement and Evaluation course.

\section{Test of Hypotheses}

$\mathbf{H}_{01}$ : There is no significant difference between the pre-test and post-test scores of teachers' conception of assessment after attending an educational measurement and evaluation course.

Table 2. t-test summary table showing differences in teachers' conceptions of assessment

\begin{tabular}{|c|c|c|c|c|c|c|c|}
\hline Teachers' Conception & N & Mean & Std. Deviation & Df & t-value & p-value & Decision \\
\hline Pre-conception & 28 & 83.9286 & 7.44823 & \multirow{2}{*}{27} & \multirow{2}{*}{4.958} & \multirow{2}{*}{0.00} & \multirow{2}{*}{ Reject } \\
\hline Post-conception & 28 & 76.7143 & 6.91138 & & & & \\
\hline
\end{tabular}

As shown in Table 2, with a calculated t-value of 4.958, significant at 0.05 , and p-value: 0.00 less than the significant value $0.05, \mathrm{H}_{01}$ is rejected. This result connotes a significant difference in teachers' conceptions of assessment after attending an educational measurement and evaluation course. The construct conception of assessment was measured based on four sub-constructs: student accountability, school accountability, improvement and irrelevant. Further analysis was carried out to see which of the sub-constructs accounted for the difference using t-test statistics, as shown in Table 3.

Table 3. Summary of t-test showing differences in in-service teachers' conceptions of assessment

\begin{tabular}{|c|c|c|c|c|c|c|}
\hline Sub-constructs & $\mathbf{N}$ & Mean & SD & df & t-value & p-value \\
\hline \multicolumn{7}{|l|}{ Student Accountability } \\
\hline Pre-test & 28 & 26.21 & 2.99 & \multirow{2}{*}{27} & \multirow{2}{*}{2.83} & \multirow{2}{*}{$.009 *$} \\
\hline Post-test & 28 & 27.89 & 3.35 & & & \\
\hline \multicolumn{7}{|l|}{ School Accountability } \\
\hline Pre-test & 28 & 15.79 & 1.89 & \multirow{2}{*}{27} & \multirow{2}{*}{3.38} & \multirow{2}{*}{$.002 *$} \\
\hline Post-test & 28 & 17.18 & 1.57 & & & \\
\hline \multicolumn{7}{|l|}{ Improvement } \\
\hline Pre-test & 28 & 22.82 & 2.25 & \multirow{2}{*}{27} & \multirow{2}{*}{1.08} & \multirow{2}{*}{.291} \\
\hline Post-test & 28 & 23.43 & 2.71 & & & \\
\hline \multicolumn{7}{|l|}{ Irrelevant } \\
\hline Pre-test & 28 & 19.11 & 2.95 & \multirow{2}{*}{27} & \multirow{2}{*}{16.57} & \multirow{2}{*}{$.000 *$} \\
\hline Post-test & 28 & 8.21 & 1.85 & & & \\
\hline
\end{tabular}

\footnotetext{
*Significant values
} 
Table 3 indicates a mean gain pre-test/post-test score for student accountability (26.21 to 27.89) with t-value 2.83 significant at 0.05 and $\mathrm{p}$-value: 0.00 less than the significant value 0.05 , hence, significant. Similarly, there was a mean gain pre-test/post-test score for school accountability (15.79 to 17.18) with t-value 3.38 significant at 0.05 and p-value: 0.02 less than the significant value 0.05 , thus, also significant. On the improvement of teaching and learning conception, insignificant mean gain pre-test/post-test score (22.82 to 23.43) was recorded with t-value 1.08 at 0.05 and p-value: 0.29 higher than the significant value 0.05 , hence not significant. Lastly, on irrelevant conception, there was a mean loss pre-test/post-test score (19.11 to 8.21) with t-value 16.57 significant at 0.05 and p-value: 0.00 less than the significant value 0.05 , hence significant. A mean loss was recorded for the sub-construct irrelevant. The implication of this is that after attending the Educational Measurement and Evaluation course, the respondents' conception of assessment as irrelevant changed.

These results imply that three of the four sub-constructs, that is, irrelevant, school accountability, and student accountability contributed to the significance in teachers' conceptions of assessment. The insignificant mean gain recorded 0.61 (23.43-22.82) for improvement sub-construct shows that teachers who participated in the study already hold notions that assessment is for improving teaching and learning, hence the insignificant mean value of 0.61 .

$\mathbf{H}_{\mathbf{0 2}}$ : There is no significant difference between the pre-test and post-test scores of teachers' conceptions of assessment after attending an Educational Measurement and Evaluation course based on gender.

Table 4. Summary of t-test showing gender difference in in-service teachers' conceptions of assessment

\begin{tabular}{|c|c|c|c|c|c|c|c|}
\hline Gender & N & Mean & Std. Deviation & df & Cal. t & p-value & Decision \\
\hline Male & 17 & 82.2941 & 6.88989 & \multirow{2}{*}{26} & -.240 & 0.811 & Do Not reject \\
\hline Female & 11 & 86.4545 & 7.89131 & & & & \\
\hline
\end{tabular}

As shown in Table 4, with a calculated t-value of -.24 significant 0.05 , and p-value: 0.81 higher than the significant value $0.05, \mathrm{H}_{02}$ is not rejected. This finding suggests there is no significant difference in teachers' conceptions of assessment based on gender after attending an Educational Measurement and Evaluation course.

\section{DISCUSSION OF FINDINGS}

This paper examined teachers' conceptions of assessment and the assessment tasks they prefer and use with students in classrooms before and after participating in an assessment related course. Drawing from an adapted Teachers' Conceptions of Assessment Inventory Brown (2006), participants responded to a 26-item questionnaire that elicited responses regarding how they conceive assessment and their assessment task preferences before and after taking an educational measurement and evaluation course. This study echoes the findings from Chu and Fung's (2018) and Vlachou's (2018) studies, which found that teachers implement both summative and formative forms of assessment in classrooms. Further, for most teachers in this study, assessment tasks were mostly related to summative than formative assessment forms. This finding is also consistent with the results of Chu and Fung (2018) and Vlachou (2018), where teachers implemented limited portfolios, projects, and peer and self-assessment tasks.

Differences in teachers' choices of assessment tasks after attending an Educational Measurement and Evaluation course were recorded. It could be inferred that after attending the course, participating teachers' preferences for assessment tasks aligned more towards choices of assessment tasks that are summative. Specifically, out of the five assessment tasks with $50 \%$ and above pre-test and post-test differences [drama and embedded assessment (100\% $-1^{\text {st }}$ respectively), supply response/fill-in-the-gap $\left(88.8 \%-3^{\text {rd }}\right)$, matching response $\left(54.54 \%-4^{\text {th }}\right)$, socio-metric scale $\left(50 \%-5^{\text {th }}\right)$, three (supply response/fill-in-the-gap, matching response, and socio-metric scale) are purely summative while drama could be summative or formative. As found in this study, teachers' 
preferences for more summative tasks are consistent with those found among a sample of mathematics teachers in Canada, where teachers utilized more of quizzes and tests (Suurtamm et al., 2010). Similarly, studies (e.g., Afemikhe \& Omo-Egbekuse, 2011; Nwachukwu \& Ogudo, 2014) argue that primarily, Nigerian teachers utilize tests and other non-formative assessment tasks to make a judgement on students' learning. This practice, Brookhart (2011) referred to as insufficient in the development of students' procedural and critical thinking skills.

Another finding from this study (first hypothesis) document the conceptions teachers hold about assessment before and after participating in an educational assessment course. Results indicate that teachers' conceptions of assessment changed after participating in the educational measurement and evaluation course. This result relates to DeLuca and colleagues' (2019) findings who found changes in teachers' conceptions of assessment after participating in a professional learning program on assessment. This result further validates the submissions of Deneen and Brown (2016) and Wiliam and Leahy (2015), who emphasizes that teacher professional training initiatives need not be one-shot but a program that allows for repeated interaction among teachers.

Further analysis of this study's data found that teachers' conceptions of assessment did not significantly change along the axis of improving teaching and learning after participating in the course. For the three other teachers' conceptions of assessment factors (student and school accountability and irrelevance), this study recorded changes in teachers' conceptions after taking the course. A significant change in teachers' conceptions of assessment was recorded for the irrelevant factor, followed by school accountability and student accountability factors. This finding implies that teachers hold multiple conceptions of assessment. Although teachers believe that assessment is for the improvement of teaching and learning, they also firmly believe that assessment is the responsibility of students as well as teachers and schools (Brown, 2002). Multiple conceptions of assessment by teachers have been found in other studies (e.g., Gebril \& Brown, 2014; Opre, 2015), as well as a reduced rating of the irrelevance factor (e. g., Opre, 2015; Remesal, 2011; Segers \& Tillema, 2011).

The second hypothesis in this study suggests that along gender lines, teachers do not differ in their conceptions of assessment. Although data analysis in this study did not cover the relationship between teachers' conceptions and practices of assessment, studies have argued that this connection is easy to establish when conceptions and practices data are available (Brown, 2002; 2011). It can be deduced from the results of this study that teachers' descriptions of their assessment task choices relate to how they perceive assessment. For example, in this study, teachers indicated preferences for more summative assessment tasks, which refers to the accountability of assessment conception. Similarly, teachers also believe that assessment improves teaching and learning; hence, their choices for some formative assessment tasks such as embedded tasks. However, this study may not be able to establish the factors responsible for teachers' preferences and conceptions as submitted by studies that societal and cultural interference influence how teachers conceive of assessment and the assessment practices they adopt (Ayodele, 2012; Davis \& Neitzel, 2011; Gebril \& Brown, 2014).

\section{CONCLUSION}

This study concludes that Nigerian teachers engage various assessment tasks to make judgements about student learning in schools. Also, the study found that although teachers represent their conceptions of assessment with multiple factors (e. g., improvement of teaching and learning, student accountability, school accountability, and irrelevance), they tend to value one conception above the other. At the same time, this study confirms that teachers' conceptions of assessment may change after participating in professional learning programs, specifically those that are content specific such as advancing teachers' assessment pedagogies. The paper also concludes that conceptual changes may be evident when teacher professional learning spans over time. However, results from our study confirm that conceptual changes are independent of gender characteristics. 


\section{SIGNIFICANCE, LIMITATIONS, AND RECOMMENDATIONS}

Indeed, the literature stresses the importance of investigating teachers' conceptions of assessment (Barnes et al., 2015; Segers \& Tillema, 2011) and the need for such studies in specific contexts (Brown et al., 2019). Thus, this study is essential and timely as it examines a concept (teachers' conceptions of assessment) that has not received much attention in Nigeria over time. Finding from this study will be useful for all educational stakeholders in the Nigerian education space. It enumerates teachers' preferences and ideas about what assessment means to teachers in practice. Specifically, teacher educators will find results from this study useful by drawing on its findings to design future assessment-related courses that can fit teacher candidates' learning needs and introduce them to innovative assessment tasks. From this study's findings, in-service teachers and teachers undergoing professional training can gain insights into how assessment is perceived by their colleagues, which could assist in the emergence of collaborations to implement innovative assessment practices in schools.

As essential as this study presents, it is not free of limitations that future researchers need to consider when replicating or utilizing its findings for research purposes. First, this study would have provided a more robust analysis of its results if more participants were willing to participate. After several persuasions, only 28 teachers out of the 45 that have regular attendance in the educational measurement and evaluation course agreed to participate and provided useful data for this study. Thus, it is recommended that future studies widen the scope in terms of study participant plans and recruitment. Secondly, it is essential to understand how teachers developed the conceptions they mentioned; could it be through professional development, learning experiences in the course, or the design and enactment of assessment in teacher education programs in Nigeria? The study's findings may also be better understood if teachers could discuss the influence of the context where they work on their conceptions and choices of assessment tasks. Thus, this study recommends that future research should employ multiple data collection methods that could enrich the data, its interpretation, and findings.

\section{REFERENCES}

Afemikhe, A., \& Omo-Egbekuse, J. (2011). Classroom assessment in secondary schools in Nigeria. Educational Studies, 12, 1-5.

Ayodele, C. S. (2012). Transformation of continuous assessment scores among schools in Nigeria. European Scientific Journal, 8(26), 172-180.

Barnes, N., Fives, H., \& Dacey, C. M. (2015). Teachers' beliefs about assessment. In H. Fives \& M. G. Gill (Eds.), International handbook of research on teacher beliefs (pp. 284-300). New York, NY: Routledge.

Black, P., \& Wiliam, D. (1998). Assessment and classroom learning. Assessment in Education, 5(1), 7-74.

Black, P., \& Wiliam, D. (2018). Classroom assessment and pedagogy. Assessment in Education: Principles, Policy \& Practice, 25(6), 551-575.

Brookhart, S. M. (2011). Educational assessment knowledge and skills for teachers. Educational Measurement, Issues and Practice, 30(1), 3-12.

Brown, G. T. L. (2002). Teachers' conceptions of assessment (Doctoral Dissertation). The University of Auckland, Auckland, New Zealand.

Brown, G. T. L. (2006). Teachers' conceptions of assessment: Validation of an abridged instrument. Psychological Reports, 99, 166-170.

Brown, G. T. L., \& Hirschfeld, G. H. F. (2008). Students' conceptions of assessment: Links to outcomes. Assessment in Education: Principles, Policy \& Practice, 15(1), 3-17.

Brown, G. T. L. (2011). Self-regulation of assessment beliefs and attitudes: A review of the students' conceptions of assessment inventory. Educational Psychologist, 31(6), 731-748.

Brown, G. T. L., Gebril, A., \& Michaelides, M. P. (2019). Teachers' conceptions of assessment: A global phenomenon or a global localism. Frontiers in Education 4(16), 1-13.

Chu, M-W., \& Fung, K. (2018). Relationships between the way students are assessed in science classrooms and science achievement across Canada. Research in Science Education, 50(2), 791-812.

Davis, D. S., \& Neitzel, C. (2011). A self-regulated learning perspective on middle grades classroom assessment. Journal of Educational Research, 104, 202-215. 
DeLuca, C., Chapman-Chin, A., \& Klinger, D. A. (2019). Toward a teacher professional learning continuum in assessment for learning. Educational Assessment, 24(4), 267-285.

Deneen, C. C., \& Brown, G. T. L. (2016). The impact of conceptions of assessment on assessment literacy in a teacher education program. Cogent Education, 3(1), 1-14.

Federal Government of Nigeria (2004). National Policy on Education. Lagos: NERDC press.

Gebril, A. (2017). Language teachers' conceptions of assessment: An Egyptian perspective. Teacher Development, 21(1), 81-100.

Gebril, A., \& Brown, G. T. L. (2014). The effect of high-stakes examination systems on teacher beliefs: Egyptian teachers' conceptions of assessment. Assessment in Education: Principles, Policy \& Practice, 21(1), 16-33.

Gebril, A., \& Eid, M. (2017). Test preparation beliefs and practices: A teacher's perspective. Language Assessment, 14, 360-379.

Jurow, A. S., Tracy, R., Hotchkiss, J. S., \& Kirshner, B. (2012). Designing for the future: How the learning sciences can inform the trajectories of preservice teachers. Journal of Teacher Education, 63(2), 147160.

Kane, M. T., \& Wools, S. (2020). Perspectives on the validity of classroom assessments. In S. M. Brookhart \& J. H. McMillan (Eds.), Classroom Assessment and Educational Measurement (pp. 11-26). New York, NY: Routledge.

McMillan, J. H. (2015). Classroom assessment. International Encyclopedia of the Social \& Behavioral Sciences, 3, 819-824.

Ndubueze, M. O., Iyoke, J. O., Okoh, S. C., \& Akubuilo, B. N. (2015). Trends in educational evaluations in Nigeria: Issues and challenges. Journal of Education and Practice, 6(21), 71-76.

Norton, L. S. (2009). Action research in teaching and learning: A practical guide to conducting pedagogical research in universities. Abingdon: Routledge.

Nwachukwu, P. O., \& Ogudo, A. P. (2014). The standard of teachers' assessment practices in three domains of learning in Nigerian secondary schools. Developing Country Studies, 4(14), 179-184.

Offerdahl, E. G., \& Tomanek, D. (2011). Changes in instructors' assessment thinking related to experimentation with new strategies. Assessment \& Evaluation in Higher Education, 36(7), 781-795.

Ogunjimi, M. O., \& Lawal, B. M. (2020). Lower and middle basic school teachers' conceptions of classroom assessment in Ilorin Metropolis. Journal of Evaluation, 5, 161-169.

Omebe, C. A. (2014). Continuous assessment in Nigeria: Issues and challenges. International Journal of Humanities, Arts, Medicine and Sciences, 2(9), 89-96.

Opre, D. (2015). Teachers' conceptions of assessment. Social and Behavioral Sciences, 209, 229-233.

Owolabi, H. O. (2016). The concept of research. In H. O. Owolabi (ed.), Educational Research Design, (pp. 17). Ilorin, NG: Published by Department of Social Sciences Education, Faculty of Education, University of Ilorin.

Remesal, A. (2011). Primary and secondary teachers' conceptions of assessment: A qualitative study. Teaching and Teacher Education, 27, 472-482.

Sadler, I., \& Reimann, N. (2018). Variation in the development of teachers' understandings of assessment and their assessment practices in higher education. Higher Education Research \& Development, 37(1), 131144.

Segers, M., \& Tillema, H. (2011). How Dutch secondary teachers and students conceive the purpose of assessment? Studies in Educational Evaluation, 37, 49-54.

Suurtamm, C. (2004). Developing authentic assessment: Case studies of secondary school mathematics teachers' experiences. Canadian Journal of Science, Mathematics, and Technology Education, 4(4), 497-513.

Suurtamm, C., Koch, M. J., \& Arden, A. (2010). Teachers' assessment practices in mathematics: Classrooms in the context of reform. Assessment in Education: Principles, Policy \& Practice, 17(4), 399-417.

Tigelaar, D. E. H., \& Beijaard, D. (2013). Special issue: Formative assessment and teacher professional learning. Teachers and Teaching: Theory and Practice, 19(2), 109-114.

Vlachou, M. (2018). Classroom assessment practices in middle school science lessons: A study among Greek science teachers. Cogent Education, 5(1), 1-19.

Wiliam, D., \& Leahy, S. (2015). Embedding formative assessment: Practical techniques for K-12 classrooms. West Palm Beach, FL: Learning Sciences International. 